\title{
An alternate (and old-fashioned) view of Neolithisation in Greece
}

\author{
Catherine Perlès \\ Institut Universitaire de France, Université Paris X, F \\ perles@mae.u-paris10.fr
}

\begin{abstract}
Despite the recent renewal of indigenous models for the Neolithisation of Greece, this paper will go back to more old-fashioned models, and argue in favour of colonisation processes by small, maritime, pioneer groups that later interacted with local populations. This argumentation rests first on an analysis of the presently available data on the Mesolithic, which shows that none of the prerequisites of a local process is met. Second, it rests on the consideration of often-neglected aspects, such as the theoretical and practical knowledge implied by the adoption of agriculture together with the adoption of new crafts and architectural techniques. Third, it rests in the need to explain the random, but strong parallels between the Near-Eastern and Greek Neolithic.
\end{abstract}

IZVLEČEK - Kljub sodobnim avtohtonističnim modelom neolitizacije Grčije se v članku vrnemo nazaj $k$ bolj staromodnim modelom in zagovarjamo kolonizacijski proces z majhnimi, morskimi pionirskimi skupinami, ki so kasneje prišle v stik z lokalnim prebivalstvom. Naše dokazovanje temelji, prvič, na analizah trenutno dostopnih podatkov o mezolitiku, ki kažejo, da ni izpolnjen nobeden od pogojev za lokalni proces. Drugič, temelji na razmišljanju o pogosto spregledanih vidikih, kot je na primer ta, da so s prevzemom teoretičnega in praktičnega znanja kmetovanja prevzeli tudi nove obrti in arhitekturne tehnike. In tretjič, naše dokazovanje temelji na potrebi, da bi razložili naključne, toda močne paralele med bližnjevzhodnim in grškim neolitikom.

KEY WORDS - Greece; Neolithization; migration

\section{INTRODUCTION}

When he recently discussed, in this same Seminar, the introduction of the Neolithic in Greece, Kostas Kotsakis (2001) strongly rejected classical migrationists models, and expressed doubts even on the "moderate colonisation hypothesis". In other words, even the presence of "scattered immigrants" remained, in his eyes, at best conjectural (Kotsakis 2001.68). In my view, to the contrary, the analysis of the data, especially from an anthropological and cognitive point of view, makes the presence of small groups of immigrants an inescapable conclusion (Perlès 2001).

By stating this, I acknowledge that I have still not disengaged myself, in my approach to the Neolithic of Greece, from "its usual archaeological referents i.e. domesticates and material culture" (Kotsakis 2001.69). However, I do not, for that matter, consider myself as a crude "materialist" or "positivist phenomenalist" of the 70's (idem). It is one thing to claim that Neolithic transformations were induced by economic or materialistic factors. It is an entirely different thing to claim, as I do, that economic and technical transformations go hand in hand with profound social transformations, and are amongst the best evidence we have to analyse these transformations. Thus, even if our models of interpretation aim at understanding, first and foremost, social processes rather than transformations in the material culture, they must, nevertheless, fully account for the observed data. 
In this respect, we shall first examine briefly the available data for the Mesolithic in Greece. Despite severe taphonomic problems, the overall picture is coherent and congruent with what is known in most of the Balkans and Mediterranean areas. On this basis, I shall argue that the Mesolithic, as known of today, does not meet the prerequisites for a purely local social and economic dynamic towards the Neolithic. Secondly, and despite some claims to the contrary, all key elements of the Neolithic socio-economic system and symbolism seem to appear simultaneously in Greece, without demonstrated local antecedents or "pre-adaptations". In these conditions, I shall argue that the hypothesis of simple exchanges between local groups and foreign farmers, without any direct demic contribution, raises severe problems.

Finally, I shall try to solve some long-pending problems about the origins of potential colonisation movements, by supporting a model of "insular colonisation" from multiple origins, the only model, in my opinion, that can solve the "perplexities of material culture that seem to vex diffusionists and migrationists", as aptly expressed by Kotsakis (2001.68).

Although this paper will thus focus on the non-indigenous elements in the constitution of the Neolithic in Greece, I do not claim that the new settlements were created in a human and social void. Zvelebil has recently presented a refined model of the various kinds of interaction that could take place between hunter-gatherers and farmers, whichever their origin, and which can usefully be applied to Greece (Zvelebil 2000; 2001). The earliest farmers in Greece readily adopted the local transverse arrowheads, and seemingly exploited already established procurement systems for obsidian'1 (Perlès 1988; 1989). They may also have adopted from local groups the cremation of the body, a funerary ritual virtually unknown in the Near-East, but already practised in the Mesolithic of Greece. As underlined by Jeunesse (2000), referring to the Danubian, the adoption of such highly symbolic cultural elements demonstrates a strong and balanced interaction between the two communities. Nevertheless, I do not consider this to imply that the "autochthonous component", to retain Jeunesse's term, was itself engaged in a process towards more complex societies and a productive economy.

\section{AN ANALYSIS OF THE PRESENTLY AVAILABLE DATA FROM THE MESOLITHIC IN GREECE}

I shall here use the term Mesolithic in its chronological sense, to designate early Holocene hunter-gatherer assemblages, between ca 8700 to $7000 \mathrm{BC}$ in calendar years. The sites identified are scarce (a dozen at most), and consist of caves and small open-air settlements. Although these settlements reveal diverse adaptations to varied environments, including the intensive exploitation of marine resources, the Mesolithic from Greece shows none of the conditions that Gebauer and Price, after the analysis of a worldwide survey, have considered to be "necessary for the transition to agriculture" (Gebauer and Price 1992.8-9).

\section{"Agriculture first appears in areas with an abundance of resources - the land of plenty - rather than scarcity". Was thus Greece a "land of plenty" in the early Holocene?}

The first noteworthy element is the limited role played in the subsistence system by the hunting of large or medium-size ungulates such as deer, boar and wild capra, according to the data from Franchthi Cave, Klissoura, Theopetra, Sidari and Kyklop's Cave. Large and medium-size game seems to have been scarce or of difficult access. This was only partially compensated by the exploitation of smaller mammals, such as hares and foxes, or by the exploitation of birds, which sometimes make up a large proportion of the hunted spectrum (Trantalidou 2003). On the other hand, a diachronic analysis of the Franchthi data shows a dramatic increase, in the Mesolithic, of the density of plant remains and a broad spectrum of collected species: wild legumes, wild cereals (oats and barley), fruits, bulbs and roots, land snails, marine molluscs, tortoises, etc (Hansen 1991). Fishing is also intensively practised on coastal sites, in particular at Franchthi, Kyklop's Cave and Sidari. Yet, claiming that the Greek Mesolithic as a whole was turned towards the exploitation of marine resources would be too extreme: several sites, further away from the coast, do not practice fishing. Even at Franchthi, intensive tuna fishing is only temporary. According to the ${ }^{14} \mathrm{C}$ dates, it corresponded to a few hundred years ( 2 or 3 centuries), as compared with the two millennia covered by the Mesolithic. Only Kyklop's cave, most probably a specialised site, shows a continuous emphasis on fishing,

\footnotetext{
1 The process may have been akin to that suggested by Gronenborn (1997) with the procurement of flint from the Maas valley by the earliest LBK colonists which reached the upper Rhine valley.
} 
but on smaller species such as the sea bream (Mylona 2003; Powell 2003). Thus, in most cases the resources exploited were small "r-selected" resources, of limited energetic yield compared with the cost of procurement and processing. This predominance of r-selected resources, be they small seeds, molluscs, hare or medium sized fish, is indicative, in my opinion, of a lack of higher-ranked species, such as tuna or large game. Similarly, the diversity of the collected plants and molluscs shows that none was available in large enough quantity to allow for intense exploitation and storage, contrary to what obtained, for instance, in the Natufian. The diet was broad and certainly balanced, but the acquisition and processing costs were high 2 . There is no indication that Greece, at the time, could have been considered "a land of plenty".

\section{"Agriculture appears and spreads quickly in areas where hunter- gatherers already occupy all of the inhabitable eco-zones"}

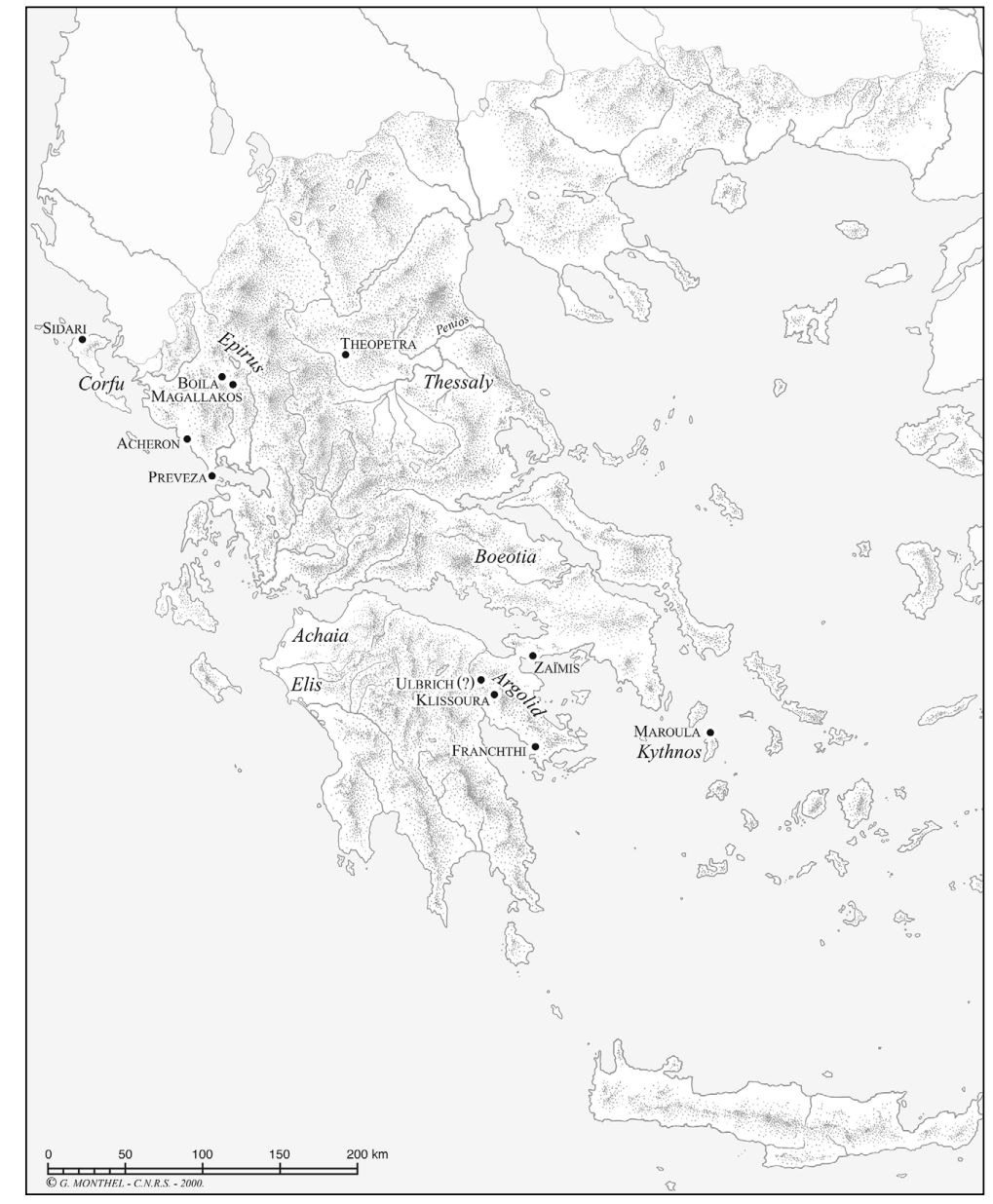

Fig. 1. Map of Mesolithic sites in Greece (after Perlès 2001).
The distribution of Mesolithic sites in Greece, as known of today, reveals a very low overall density and a preference for locations providing access to varied environments. Aside from Kyklop's Cave, located on a small island and probably a specialised site focussing on the exploitation of marine resources, all sites give access to hilly interiors, coastal plains, marshes, lakes or to the sea. Significantly, the large inner alluvial basins seem to have been deserted. However, the minute number of sites known implies, if only for demographic reasons, that a much greater number of sites have been destroyed or not recovered. Yet Greece is a well-surveyed country, and many inner basins have been intensely fieldwalked. In several areas, including Thessaly, the natural sections along the rivers have also been systematically explored (Chavaillon et al. 1967; 1969; Runnels 1988; 1994; Wells 1996, etc.). Middle Palaeolithic sites, buried under deep alluvium, have been discovered during these surveys. The fact that no late Upper Palaeolithic or Mesolithic sites came to light is thus significant. It is also significant that all Upper Palaeolithic settlements from Epirus were deserted at the dawn of the Holocene and that no Mesolithic occupation was ever discovered at the basis of Neolithic settlements. The absence or low density of Mesolithic sites in well-surveyed basins and in stratified shelters can be considered as established. Even in areas were Holocene alluviation was limited in extent, no Mesolithic site was identified (Jameson et al. 1994; Cavanagh et al. 1996; Wells 1996). Large areas were clearly devoid of settlements, and even if we are missing a large number of sites, we are far from a situation whereby one could state that "hunter-gatherers already occupy all of the inhabitable eco-zones".

\section{"Agriculture appears initially among more se- dentary and complex groups of hunter-gathe- rers"}

There is no evidence in Greece, during the Mesolithic, for either semi-sedentary or complex huntergatherers. None of the Mesolithic sites in Greece has 
produced the architectural features, storage features, heavy equipment, remarkable artistic productions and diversified techniques associated with the sedentary hunter-gatherers of the Natufian or with the rich Mesolithic settlements of Northern Europe. No architectural remains have been uncovered, and the archaeological inventories show, on the whole, little variety and minimal technical investment. There is no indication whatsoever that these groups were involved in a process of sedentism or intensification of resources exploitation. The chipped stone tools reflect the isolation of Greece at that period, a point to which I shall come back. Flake tools, such as crude endscrapers, sidescrapers, notches, and denticulates dominate these assemblages. The latter are either almost devoid of microliths (i.e. the Lower Mesolithic and Final Mesolithic at Franchthi) or full of microliths (the Upper Mesolithic of Franchthi, Sidari), but of shapes and techniques unknown elsewhere.

Bone tools are known from Franchthi and Kyklop's cave. At Franchthi, they comprise awls and heavy points, but no implement that can be associated with fishing. To the contrary, Kyklop's Cave has yielded a number of fine bipoints and fish-hooks of complex manufacture (Moundrea-Agrafioti 2003) 3 . Despite the presence of wild cereals, grinding tools are very rare and mostly consist of hand stones on natural pebbles. No mortar or grinding slab has been securely attributed to the Mesolithic so far. A large number of beads were found associated with the Mesolithic burials at Franchthi, but they mostly consist of unworked Dentalia and pierced Cyclope neritea.

The few burials known, from Franchthi and Theopetra, (Cullen 1995; Kyparissi-Apostolika 2000; 2003) yielded no conspicuous grave goods. There is no indication of social differentiation between individuals, and nothing, given the available data, that would indicate a complex social organisation. This essential condition for the development of a local dynamics of Neolithisation is also not met.

\section{"There is a long period of availability of culti- gens and/or domesticated animals prior to full adoption of agriculture"}

This statement refers to the long phase of "stasis" observed, in all contexts of primary Neolithisation, between the first presence of domesticated species and the adoption of a fully developed farming eco- nomy (Gebauer and Price 1992; Hayden 1992). In the Near East, for instance, more than a millennium separates the first presence of domesticated plants from the full adoption of an agro-pastoral economy (Cauvin 1997), and the time gap since the first attempts at plant cultivation must be even longer ( $\mathrm{Go}^{-}$ pher et al. 2001).

In Greece, the presence of wild cereals and pulses in Mesolithic assemblages, well before any trace of agriculture was introduced, has often been quoted as an evidence of a "pre-adaptation" stage to agriculture (i.e. Chapman 1994; Halstead 1990). However, there is no sign that these species were intensely exploited or preferred to others. Oats and barley make up only a small proportion of the seed assemblages at Franchthi (ca 15\%), and the latter actually disappears in the latest phase of the Mesolithic, prior to the appearance of a domesticated form (Hansen 1991). As for the "wild einkorn" which was recently found in Greece (Zamanis et al. 1988) and which could have been locally domesticated (Kotsakis 2001), it has been shown beyond doubt to be a domesticated wheat returned to the wild (Heun et al. 1997; 1998). Finally, let us note that if the mere exploitation of wild species, be they wild goats, wild boars, wild cereals or wild legumes, is to be considered as a "pre-adaptation" to their domestication, then most of the Palaeolithic also should be considered as a pre-adaptation stage to the Neolithic.

After the introduction of domesticated plants and animals, no "stasis" is observed, either. There, as in most Mediterranean countries, agriculture, once introduced, is very rapidly adopted and generalised (Dennell 1992). In all newly founded settlements, domesticated plants and animals heavily predominate in the seed and bone assemblages (Perlès 2001). There is evidence, nevertheless, that at that stage late Mesolithic hunter-gatherers did have access to domesticates. At least, this is how I have interpreted the "Initial Neolithic" at Franchthi, with its strong Mesolithic traditions and selected domesticates (Perlès 2001), or the presence of domesticates with unusual pottery sherds at Sidari. Bones of domesticated mammals have also been found in late Mesolithic levels at Theopetra and Kyklop's Cave. However, given the stratigraphic problems in both sites, direct dating of the bones will be needed before contamination can be ruled out (Newton 2003; Trantalidou 2003). In any case, none of these cases would establish that

\footnotetext{
3 Although, considering their strong resemblance to Neolithic hooks and the disturbances at the site, direct AMS dating of these pieces would make their dating more secure.
} 
cultigens and domesticated animals were available "long before" the full adoption of agriculture. In all these sites the late Mesolithic ${ }^{14} \mathrm{C}$ dates are contemporaneous with the earliest dates for fully agro-pastoral settlements. The presence of domesticated species can just as well be taken as evidence for the expected interactions between the first farming communities and the local hunter-gatherers.

\section{"The transition to agriculture appears to be ac- companied by a shift from a communal to hou- sehold level of organisation"}

Given the nature of the remains pertaining to the Mesolithic in Greece, not much can be said about the nature of the socio-economic organisation. Nevertheless, two points can be made. First, the collective burial at Franchthi that Tracey Cullen brought to light recently (Cullen 1995) contained the inhumations of four adults (one male and three females), an infant, plus two cremations (two young adults, one male and one female). This might fit the hypothesis of a communal, rather than household, level of organisation. Secondly, and contrary to what obtains in the Near East from the Natufian to the PNA, no shift can be perceived in the nature of sites, organisation of sites, or organisation of activities throughout the Greek Mesolithic. Overall, the Mesolithic in Greece, as known of today, reflects a mobile way of life by groups that exploited a wide array of seasonally available resources. Some at least were skilled seafarers, able to navigate difficult seas, bring back obsidian from Melos, and catch heavy prey such as tuna-fish. Nevertheless, none of the conditions that Gebauer and Price identified as necessary for the transition to agriculture on the basis of their world-wide ubiquity is met in Mesolithic Greece.

Obviously, this evaluation rests on the presently available data, and the latter is extremely limited. Andreou and his colleagues (1996) consider that, on this basis, no valid comparison may be drawn between the Mesolithic and the Neolithic and no conclusion can be reached regarding the origins of the latter. Even more recently, Kotzakis reaffirmed the possibility that Mesolithic (or transitional Mesolithic/ Neolithic sites) could be buried under alluvium or submerged by the rise in sea level (Kotsakis 2001. 66), thus obscuring a local dynamic towards more complex societies. However, I have already said that Greece was a well-surveyed country. In addition, if a local dynamic towards more complex and more sedentary societies had taken place, the settlements would have become all the more important and ar- chaeologically visible. This is well exemplified, not only by the Near and Middle East with the Natufian and Quermezian settlements, but also, for instance, with the Iron Gates Mesolithic (Radovanovic 1996) or the Ertebølle complex (Larsson 1990).

I thus concur with Jacobsen (1993) or Runnels (1995), for instance, in considering that:

- Greece was sparsely populated during the Late Palaeolithic and the Mesolithic.

- Most sites were located in areas with access to varied environments, including coastal or inland plains and hilly hinterlands. To the contrary, I consider that the absence of sites in the centre of the large alluvial basins reflects a real archaeological pattern. In this respect, I do not consider Theopetra as an exception: though it belongs administratively to Thessaly, it is located on the very margin of the Thessalian plain, in a diversified environment backed by the Meteores and the Pindus mountains.

- The low visibility of the Mesolithic (except, of course, in caves) is a reflection of a mobile way of life, leaving behind short-term camps with a low density of remains.

In these conditions, I also consider that the contrast with Early Neolithic sites, in terms of density of sites, settlement patterns, economic basis, and technology is significant and not merely the outcome of recovery biases.

\section{THE INTRODUCTION OF THE NEOLITHIC AS A FULL "PACKAGE"}

By $7000 \mathrm{BC}$ indeed, we start to find permanent villages with built houses and with an entirely new technological inventory that includes pressure-flaked blades of obsidian and flint, polished axes, diverse bone tools, manufactured ornaments, fired clay artefacts, figurines, etc. The economy is based almost exclusively on the exploitation of domesticated plants and animals, most of them of definite Near Eastern origin: sheep, goats, pigs and cattle for the animals, wheat (Triticum monococcum, T. dicoccum, T. aestivum), barley (Hordeum vulgare ssp. distichum), pulses (Lens culinaris, Vicia ervilia, Pisum sativum) for the plants (see Gopher et al. 2001 and Lev-Yadun et al. 2000 for a synthesis of genetic analyses of the origins of the domesticated plants).

Pottery (but not baked clay objects) is the only typically Neolithic element that might be missing in the 
earliest Neolithic sites, i.e. during the phase that I prefer to call "Initial Neolithic" rather than "Aceramic Neolithic" (see discussions in Bloedow 1991; 1992/ 1993; Perlès 2001).

Not surprisingly, the notion that the Neolithic was introduced as a "package" is best exemplified at Knossos. Knossos is the only Initial Neolithic site that has benefited from recent and very careful excavations, and the results, according to the excavators, are unambiguous (Efstratiou et al. in press).

"The Neolithic settlement of Knossos was founded on the Kephala hill at the end of the $8^{\text {th }}$ millennium BC, sometime around $7000 \mathrm{BC}$, as the new ${ }^{14} \mathrm{C} / \mathrm{AMS}$ early date coincides with Evans's dates (Fig. 7). The first occupants, a small community, arrived in the area bringing with them the full Neolithic 'package', but not pottery. All the bones retrieved indicate fully domesticated animals such as goats, sheep (ovis/ capra), pigs (Sus scrofa), cows (Bos), and dogs (Canis familiaris), all belonging to small-sized animals showing no signs of any proto-domestication process. The agricultural economy is characterised by fully domesticated plants such as cereals (Triticum sp.) and legumes (Pisum sp.) - and not just cereals as Helbaek reports (Evans 1968.269) - that show no evidence of any transitional stage from wild to cultivated plants (wild einkorn and barley). A. Sarpaki who examined the pertinent material emphatically stresses that while systematically exploiting trees, specifically almonds (Amygdalus communis) and figs (Ficus carica), the first Knossians were well advanced in cultivation practices and not mere beginners".

This sudden appearance of a "Neolithic package" is a key element in the argumentation in favour of a colonisation process, and it can hardly be challenged in the case of Crete. To the contrary, it has recently been challenged for Continental Greece (Kotsakis 2001; Thissen 2000a; 2000b). As pointed out by Kotsakis, there is little overlap between the Mesolithic and Neolithic dates in Greece, taken as a whole. Following Thissen, he suggested, nevertheless, that the Neolithic was introduced to Thessaly several hundred years after its introduction to Crete and to the Peloponese (Kotsakis 2001.67). He thus concluded that "in any case, even if migrationists hypotheses are justified for Thessaly, there was enough time scope for these scattered immigrants to build a relation with local populations and surroundings and interact with them in local palimpsests", although he admits that the "the early sites that would potentially picture this interactive process are still missing from the archaeological record" (ibid.). I fail to see, however, which are the arguments for a later Neolithic occupation of Thessaly. Fifteen radiocarbon dates can be attributed to "Aceramic" or "Initial Neolithic" levels in Greece, coming from four different sites4. As observed by Bloedow (1992/1993), none of these dates is individually devoid of a problem, but the same would apply to any series of Neolithic dates, especially from long-duration, stratified settlements. Aside from three late samples, all the dates cluster between 7050 and 6500 calBC (calibrated at 2 sigma). Two of the four dated Initial Neolithic sites are located in Thessaly: Sesklo and Argissa. The dates of these deposits do not depart from those of Franchthi and Knossos. Argissa gave four dates with maximum probabilities between 7422 and 6544 calBC, and Sesklo gave one date with a maximum probability at 6542 cal BC (Perlès 2001.Tab. 5.3).

Significantly, all these dates come from deposits located at the bases of long sequences and underlie classic "Early Neolithic" deposits, as defined by their pottery. I do not intend to discuss here the presence of pottery in Initial Neolithic levels, but they do represent, in my opinion, an early phase of the Neolithic in Greece, already characterised by a fully developed agro-pastoral economy and typically Neolithic

4 I thank N. Efstratiou for providing me the new AMS date from Knossos. 
assemblages. This early phase is followed by the classic "Early Neolithic" (pre- and proto-Sesklo in Thessaly), dated, by more than 50 samples, to ca 6500 to 5900 calBC, and in complete continuity with the Initial Neolithic dates. Thus, the Initial and Early Neolithic extend approximately one millennium, half the duration of the Mesolithic. There is no convincing evidence for a process of diffusion in steps having occurred on a large scale. For instance, the suggestion that the Early Neolithic at Franchthi consisted of two separate episodes, as the ${ }^{14} \mathrm{C}$ dates might suggest (Thissen 2000a; 2000b), cannot be substantiated, since the thick Early Neolithic deposits on the Paralia could not be radiocarbon-dated.

\section{EXCHANGES OR COLONISATION?}

How, then was this Neolithic package introduced into Greece? Since no one can deny that a majority, if not all domesticated species, come from the Near East, the alternative to colonisation is that of acquisition through exchanges. In this case, no movement of Near-eastern groups needs to have taken place. In this sense, the spread and development of the Neolithic in Greece would have remained a strictly indigenous phenomenon, based on the internal dynamics of these groups (Kotsakis 1992; 2001; Kyparissi-Apostolika 2003). It seems, though, that too little thought has been given to the very notion of "exchanges" and to their practicability. First, exchanges with whom? There are no indications of contacts between Greece and the Near East during the Mesolithic. In addition, it must be recalled that the dates for the earliest Neolithic settlements in Western Anatolia and Turkish Thrace are substantially later than the dates of the Initial Neolithic in Greece (Thissen

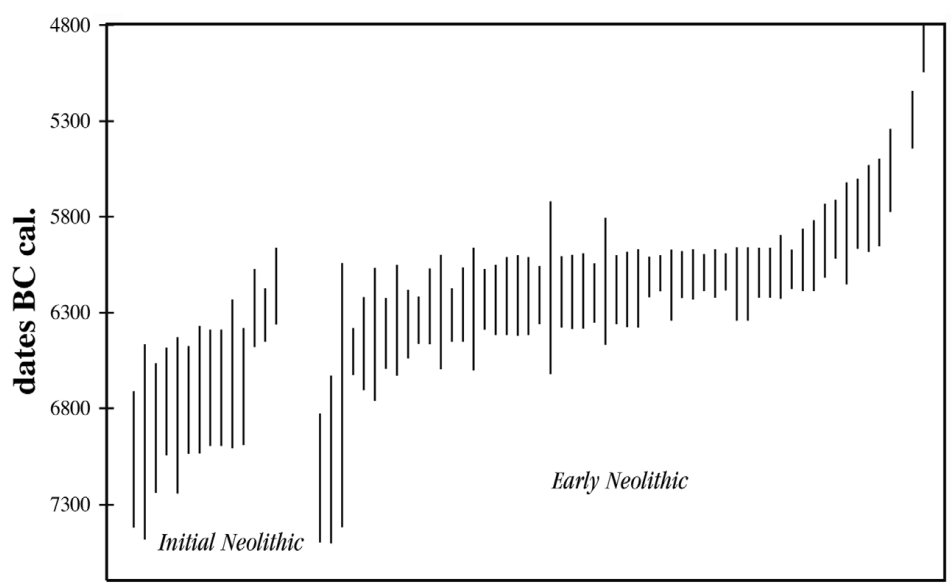

Fig. 3. ${ }^{14} \mathrm{C}$ dates (cal BC, two standard-deviations) of "Initial Neolithic" and Early neolithic sites in Greece. The new date "Initial Neolithic" date from Aceramic Knossos has not be added. 2000c). Second, "exchanging" live domesticates is not like exchanging a pot, a meat-joint or an ornament. As underlined by Zilhão (1993.54): “...it might be difficult for hunter-gatherers to reconcile the possession of domestic animals with their traditional economy, given the incompatibilities in terms of mobility and timing of resource acquisition that such a possession might imply..."

In a longer-term perspective, a knowledge of the habitats, specific requirements, breeding, cultivation and storage techniques for approximately 15 new domesticated species would have been needed if these species were to survive and develop, as they did. Considering the breadth of knowledge, knowhow, experience, and skills implied by the simultaneous introduction of domesticated plants and animals, as well as the current lack of evidence for a "pre-adaptation" stage, I find it doubtful that such abstract and especially practical knowledge could have been "exchanged" and passed on, along with the animals and plants, without the active participation of the original farmers. In addition, it must be recalled that the new elements introduced into Greece also concern building techniques, chipped and polished stone tools, bone tools, stone vases, clay firing, etc. The breadth of knowledge this implies is quasiencyclopaedic, and is certainly severely underestimated under the hypothesis of simple exchanges. Furthermore, the communication of abstract knowledge and subtle practical skills requires far more common linguistic background than the mere exchange of artefacts. Such bilingualism could only have been acquired through repeated contacts, of which Mesolithic Greece offers no indication. Thus, the "simple" hypothesis of exchanges actually raises many more problems than that of small groups of colonists, who would have brought along their animals, their plants, their knowledge and their skills.

Although the supporting arguments might have been different, this position is not new (Weinberg 1970). To the contrary, it might almost be deemed oldfashioned. There has thus been ample time for criticisms, and one of the most powerful was the impossibility of pinpointing a clear origin for these presumed colonists. It is indeed easy to find parallels between the Near-Eastern PPN Neolithic and the earliest Greek Neolithic, but these parallels do not converge towards a single, core area. 


\section{THE PARALLELS BETWEEN GREECE AND THE NEAR EAST}

These parallels pertain to two different levels. First, the structural analogies, second the artefactual analogies.

\section{Structural analogies}

Structural analogies underline the fact that the similarities concern not only which plants and animals were exploited, but more fundamentally, how they were exploited, how space was exploited and socialised, how the world was organised. In other words, to use a fashionable expression, the "domestication of space" is the same in the Near East and in Greece: - First, the settlements in both regions consist of clustered, permanent, villages.

- Within the village, houses are of the same quadrangular shapes and similar dimensions, which seem to correspond to individual domestic units.

- The architecture is also comparable, with a prevalence of clay for the walls (mud-bricks or daub), but also for clay benches, hearths, and basins. The "furniture" is integrated into the very architecture of the house.

- Outside the settlement proper, similar parallels can be found in the way space was exploited. The most striking aspect is the opposition between a small, well-defined, permanent exploitation territory and a "procurement" area of extremely vast dimensions. In Thessaly, the area of densest settlement during the Early Neolithic, the theoretical territory around each village does not exceed 450 hectares, judging by the mean distance between first-order nearest neighbours (Perlès 2001). By contrast, some goods such as obsidian and flint blades circulate an area that extends over hundreds of kilometres, over lands and seas.

A shared characteristic with the Near East (Cauvin and Cauvin 1982.48) is the absence of an intermediate zone, or "saltus", between this vast procurement zone and the very small village territory. Contrary to what obtains in other regions of Europe, there is no indication during the Early and Middle Neolithic in Greece of a complex organisation of activities on an intermediate scale, with hunting camps, transhumant sites, animal pens, fishing grounds, etc. The absence of "saltus" may be related to ideological factors as much as to economic factors. On the whole, Early and Middle Neolithic communities in Greece seem to have systematically ignored or even rejected wild resources, whether plants, animals, raw materials, or shelters. Wild fauna in EN sites rarely exceeds $5 \%$ in number of rests, local raw materials are often a minority, and caves are neglected. The accent is put on humanly controlled resources, on humanly built dwelling, on man-made geometric ornaments, on raw materials acquired through exchange rather than from local sources. That this is a choice is indicated by the fact that all the "wild" or "natural" elements will regain importance later, during the Late Neolithic and Bronze Age. As though, in those early phases of the Neolithic, it was necessary, for symbolic reasons, to emphasise the human control of nature5. Early Neolithic communities exploited an environment that they had artificially created, with species that they had themselves introduced, and that closely reproduced the Near-Eastern domestic ecosystem. No species was lacking, no species had been added. The two plants domesticated in Europe, the poppy and the oat, are precisely absent. I would thus conclude that the most relevant argument in favour of Near-Eastern origins is the fact that the first Neolithic communities in Greece recreated, with very little modification, not only their original biological environment, but also their conception of space. However, these features are common to most of the Near East. Thus, they cannot by themselves provide a more precise answer to the question: where from?

Stylistic analogies, taken in a broad sense (Sackett 1977) should logically point towards a more specific area of origin. There are, undoubtedly, numerous analogies between Greek and Near Eastern artefacts. But in truth these stylistic or technical analogies create more problems than solutions. The parallels, sometimes very striking, can be found in many domains: amongst the early schematic figurines, the pebble figurines, or the later coffee-bean eyed figurines; amongst the stone vases, the ear plugs, the geometric stamps; amongst the bone hooks, the cut-sherd spindle whorls, the sling bullets, the socalled "tokens", etc (Perlès 2001). More generally, the very abundance and diversity of what is often called "small finds" is a characteristic shared by both regions, and their mere presence opposes them to Western Europe. To these formal resemblances can be added technical analogies, such as the specific methods for pressure-flaking obsidian, and the already mentioned similarities in building techniques.

5 The same phenomenon can be observed in the early phases of the Danubian (Jeunesse 2002). 
But what can we do with such lists? Some of these similarities pertain to categories of artefacts with wide distributions, such as the cut-sherd spindle whorls, the sling bullets, the polished axes and adzes, which bear little stylistic investment. Consequently, they cannot help in solving the problem of origins. The same can be said of techniques such as the use of plaster or mud bricks, of very large distributions.

Secondly, there are similarities between artefacts that are stylistically very distinctive: the figurine, the bone hooks, the earplugs, the stamps, for instance. The similarities are strong, and often very striking. But their interpretation in terms of direct filiation raises severe problems:

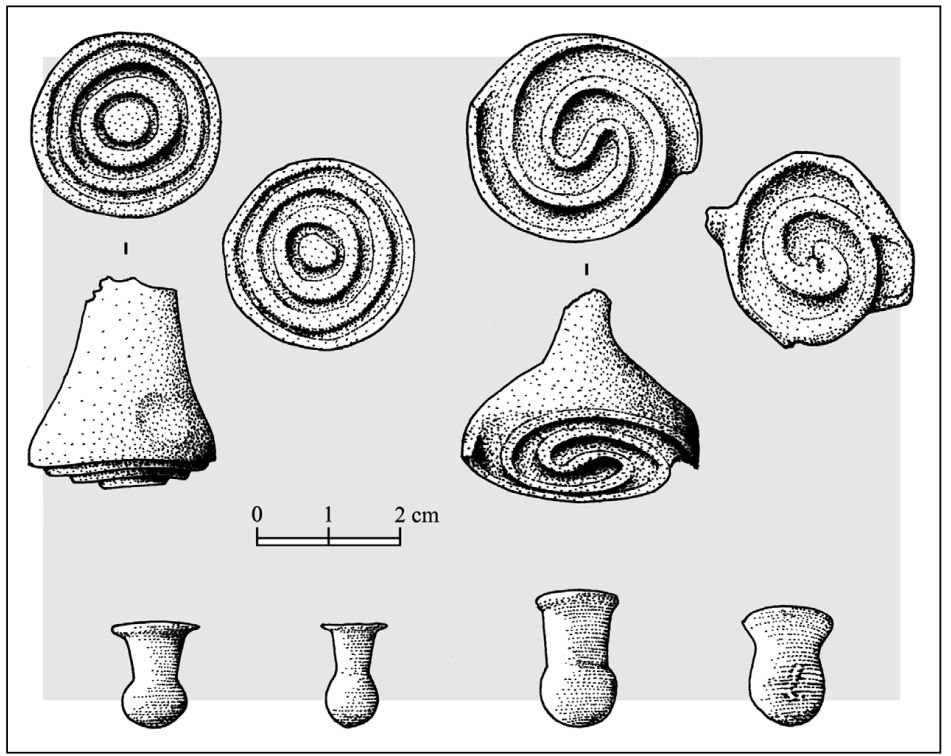

Fig. 4. Stamps and ear-plugs from Near-Eastern and Greek sites (after Perlès 2001).
- Most similarities remain contextually isolated. Undoubtedly, the bone hooks, the stamps and earplugs from Hacilar and Çatal Hüyük strongly resemble those of Thessaly. But what about the architecture, the paintings, the bulls-heads, and the

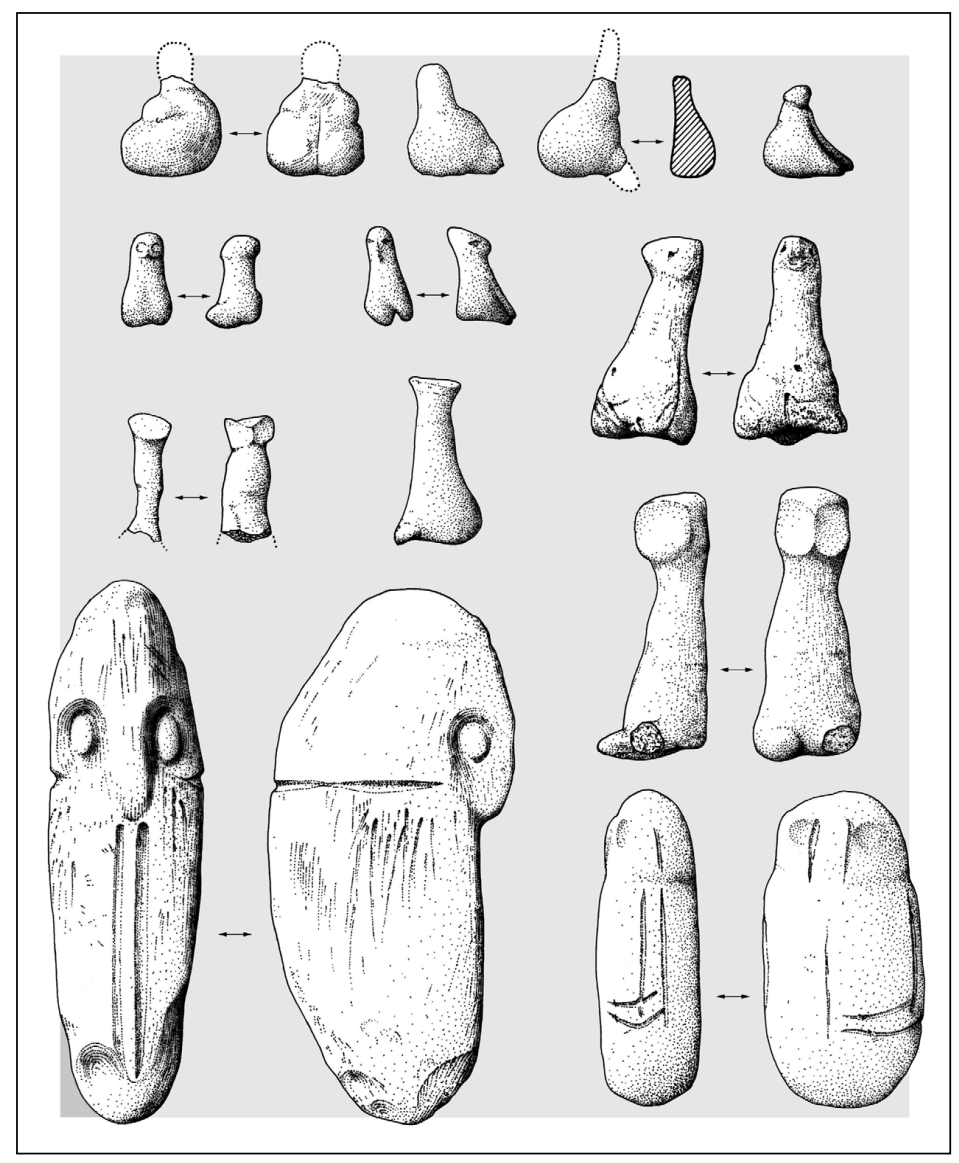

Fig. 5. Early anthropomorphic figurines from Near-Eastern and Greek sites (after Perlès 2001). obsidian mirrors of Çatal, which have no equivalent in Greece? Can we isolate one or two categories of artefacts, and ignore all others?

- There are, in some instances, important chronological differences between the specimens under comparison.

- More generally, these formal analogies cover a wide time-range and a wide region, from Anatolia to the Jordan valley. They do not converge towards a coherent spatial, temporal, and cultural unit.

It might thus seem that, as advocated by its opponents, the model of a Near Eastern colonisation cannot be substantiated, or that the problem was conceived in the wrong terms and requires, to be solved, a different model of colonisation.

\section{A MODEL OF INSULAR COLONISATION}

The radiocarbon dates from the earliest Neolithic in Greece show that, chronologically speaking, the colonisation of Greece could be a late outcome of what Cauvin called the "great exodus" of the PPNB (Cauvin 1997). Indeed, the displacement of small groups of farmers took place first and foremost within the Near East itself. These movements of colonisation were frequently accom- 


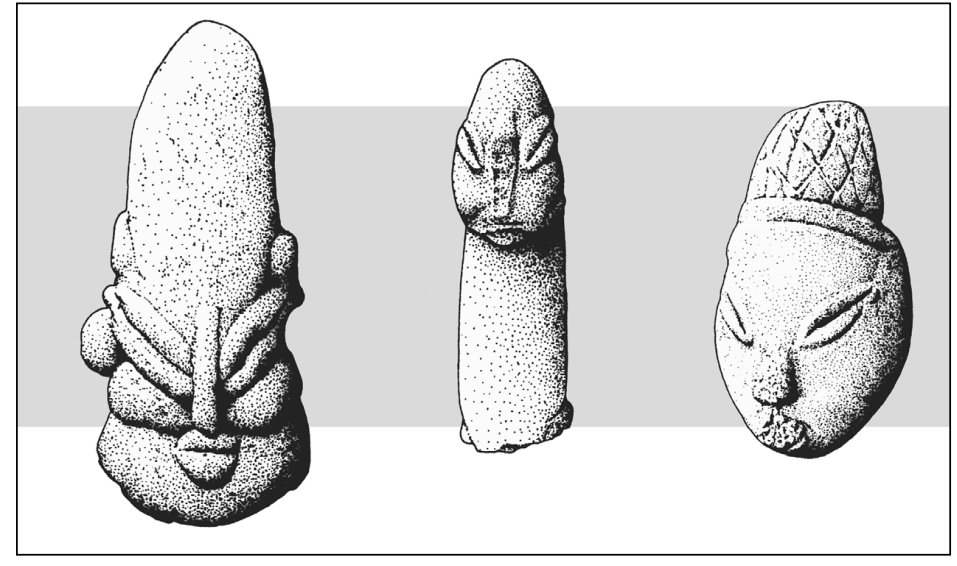

Fig. 6. "Coffee-bean" eyed figurines from Near-Eastern and Greek sites (after Perlès 2001).

panied by radical transformations in material culture, even when no local influences could be invoked (Cauvin 1997). If the colonisation of Greece were part of the same process, similar transformations could then be expected. More specifically, the colonisation of Greece could be linked to the collapse of the complex societies that mark the transition between the PPNB and the PNA, as advocated by Özdogan (1997) or Zilhão (2000). This would explain why the Early Neolithic societies in Greece retained many technical elements of the Near East, but clearly departed from the PPNB societies in their social organisation, settlements patterns and collective symbolism (Özdogan 2001).

In fact, as noted above, artefactual analogies between Greece and the Near East display two main characteristics: these are selective on the one hand, heterogeneous on the other. This obviously makes no sense if one envisions the spread of the Neolithic through the regular advance of small communities that progressively founded new villages near their original settlements. That is, if one follows the gradual "wave of advance" model of Ammerman and Cavalli-Sforza (1984), or if one follows the model usually put forward for the spread of the Danubian.

Runnels and van Andel have recently put forward an alternate model that fits the Near-Eastern data better: the rapid displacements over long distances of small groups that ultimately settled in favoured environments far from their original homes (Runnels and van Andel 1995). This model parallels, for inland areas, the "maritime leap-frog" process of colonisation suggested by Zilhao for the Mediterranean area (Zilhão 1993; 2001). The colonisation of the Levantine Coast is a good example of the first process, that of Cyprus, and even more so, of Crete (dis- cussed by Broodbank and Strather 1991), of the second process. Long distance re-settlements during the Early Neolithic are also exemplified by more intricate situations, such as the coastal Impressa settlements isolated amidst Cardial settlements in the Languedoc (Manem 2002; Roudil and Soulier 1983).

The hypothesis of long-distance expeditions certainly fits the Greek data better than that of a gradual advance. We know of no Early Neolithic settlement between Turkish Thrace and the Giannitsa basin, and no definite Early Neolithic settlement has ever been found in any of the small Cycladic islands. The well-known absence of early Neolithic sites in Greek Thrace, Eastern and Central Macedonia, has frequently been attributed to the effects of deep alluviation (Efstratiou in press). However, the areas affected by such alluviation are localised, and Palaeolithic industries have been brought to light in Eastern Macedonia (near Drama) and Central Macedonia (near Saloniki). So why are there no Early or Middle Neolithic settlements? It is also clear from the pottery that the Western Macedonian Early Neolithic sites have strong Balkan affinities (Chrisostomou 1996 (1997); Lichardus-Itten et al. 2002.130) and were probably settled from the North, not from the East. I doubt, therefore, that Eastern Macedonia was a road of penetration into Greece.

In consequence, the settlement of mainland Greece cannot, in my opinion, be compared with the slow movement of populations characteristic of the Danubian "waves of advance". There is evidence neither for a continental movement, nor for a slow progression. On the other hand, navigation was practised in the Mediterranean since the Late Pleistocene, as indicated by the presence of Melian obsidian in the Final Pleistocene and Early Holocene levels from Franchthi (Perlès 1979; 1987; Renfrew and Aspinall 1990). It is probable that regular navigation in the Aegean, whether for fishing or procuring raw materials, led to a widespread knowledge of the landmasses that existed far away. As stated by Davis (1992.702): "The recognition that the Aegean was being navigated long before the introduction of agriculture to Greece has obvious and important repercussions for how the process by which agriculture was spread from the Near East to Greece is viewed: clearly an absence of evidence for settle- 
ment in the earlier phase of the Neolithic in the Greek islands no longer requires us to postulate the existence of a more northern route of migration for Neolithic immigrants, for which there has been precious little evidence. The Aegean sea of the later Palaeolithic was navigable and navigated."

Good knowledge of navigation would have been necessary since, as convincingly argued by Broodbank and Strather in particular, the colonisation of islands such as Crete could only be successful if it resulted from planned and organised expeditions: "The maritime transfer of a nucleus of humans and domesticates suitably balanced to establish a farming community would demand sufficient planning to indicate a deliberate intent to colonise somewhere (whether the point eventually reached or not). Models of passive, accidental dispersion through stochastic or natural processes, that have been successfully applied to the colonisation of islands by certain animal and plant species, may explain some early hunter-gatherer maritime dispersions (...), but present an implausible scenario for the movement of agriculturalists together with their attendant fauna and flora" (Broodbank and Strasser 1991.237).

There is, in addition, no reason such expeditions should have proceeded as far as Crete, without reaching, at one point or another, mainland Greece. I thus suggest that the colonisation of mainland Greece, too, relates to these long-distance expeditions, well exemplified not only by the colonisation of Crete, but also of Cyprus, Corsica, or the Balearic islands. This conceptual framework, in turn, sheds new light on the problems of origins. First, these long-distance expeditions were, undoubtedly, difficult and fraught with risk (Broodbank and Strather 1991). I doubt very much that everyone would have been willing to embark in such expeditions, or that a whole Anatolian or Levantine community, for instance, would have suddenly decided to move to Thessaly! ${ }^{6}$ They would instead have concerned small groups of rather adventurous individuals, which did not carry, possess or choose to retain the whole technical and cultural heritage of their original communities. Hence the selective aspect of what analogies can be found. Secondly, these expeditions may well have been undertaken by groups of different origins. There are many different sea-routes linking the Levant and Turkey to Greece, and I see no reason to postulate a single original area. Repeated displacements of small groups, in all directions, are well exemplified in the Neolithic of the Near East (see Cauvin 1997; Huot 1994). After all, most historically documented cases of colonisation, including the Greek colonies themselves, did involve groups

6 One could, instead, recall what Platon said of those sent to create new colonies: "Tous ceux que le manque de ressources dispose et destine à suivre des meneurs pour s'emparer des biens des possédants, ces prolétaires constituent une sorte de mal intérieur de la cité. Pour s'en débarrasser sous un beau nom, on crée ce que l'on appelle une colonie. C'est la forme la plus bénigne d'expulsion." (Platon, Les Lois, 735e-736a). 
of different origins... These multiple origins would explain the heterogeneity in the parallels that can be drawn between Greece and the Near East.

My hypothesis, consequently, is that the first pioneers of Greece would have been (adventurous) individuals, continuing the PPNB "great exodus", who followed different pathways from their original ancestral "home" to their ultimate settlement in Greece. Each would have retained some, but some only, of their most valuable symbols or techniques, and this would explain the selectivity and heterogeneity of our analogies.

\section{CONCLUSION}

I shall thus conclude: (a) that the presence of foreign colonists is a necessary hypothesis when one considers the cognitive aspects of the simultaneous introduction of the whole array of Neolithic domestica-

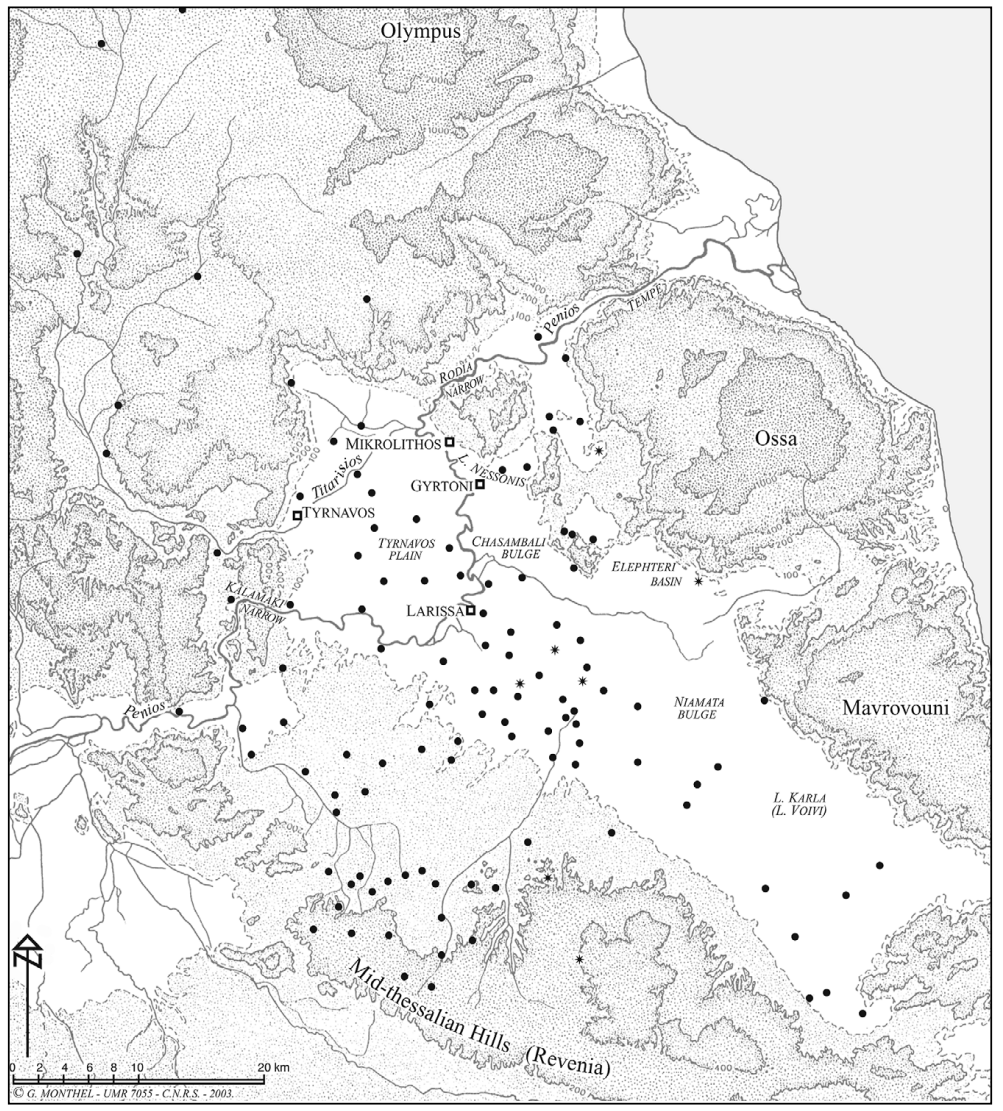

Fig. 8. Early Neolithic sites in Eastern Thessaly (after Perlès 2001). Dots: EN 2 sites. Stars: unspecified EN sites. tes and techniques and, (b) that this hypothesis has been rejected, in part, because Greece has been considered as part of the Continent, and, therefore as colonised through familiar colonisation processes. I contend that, paradoxically, Greece should be viewed as a far-off island, settled by small groups of varied origins, who rapidly assimilated themselves with the local hunter-gatherers.

I know that this view raises strong objections amongst several Greek scholars, but I fail to see why. Such long distance displacements of small groups of farmers are demonstrated in the Near East at least since the early PPNB. They are well exemplified by the colonisation of the islands, and they are clearly recorded within Europe itself during the Neolithic. It is also now widely acknowledged that the Neolithic in Europe, as a whole, is the result of complex interactions between colonist groups and local populations. I see no reason, looking at the data, to claim Greece as an exception.

\section{REFERENCES}

AMMERMAN A. J. and CAVALLI-SFORZA L. L. 1984. The Neolithic Transition and the Genetics of Populations in Europe. Princeton University Press, Princeton.

ANDREOU S., FOTIADIS M. and KOTSAKIS K. 1996. Review of Aegean Prehistory V: The Neolithic and Bronze Age of Northern Greece. American Journal of Archaeology 100: 537-597.
BLOEDOW E. F. 1991. The 'Aceramic' Neolithic phase in Greece reconsidered. Mediterranean Archaeo$\operatorname{logy}$ 4: 1-43.

1992/1993. The date of the earliest phase at Argissa Magoula in Thessaly and other Neolithic sites in Greece. Mediterranean Archaeology 5/6: 4957. 
BROODBANK C. and STRASSER T. F. 1991. Migrant farmers and the Neolithic colonisation of Crete. Antiquity 65: 233-245.

CAUVIN J. 1997. Naissance des divinités, naissance de l'agriculture. La révolution des symboles au Néolithique. Paris, CNRS Editions, 2ème éd. révisée.

CAUVIN J. and CAUVIN M.-C. 1982. Origines de l'agriculture au Levant: facteurs biologiques et socioculturels. In Young T. C., Smith P. E. L. and Mortensen P. (eds.), The Hilly Flanks. Essays on the prehistory of Southwestern Asia presented to R. J. Braidwood. Studies in ancient oriental civilization no. 36: 43-53.

CAVANAGH W., CROUWEL J., CATLING R. W. V. and SHIPLEY G. eds. 1996. Continuity and change in a Greek rural landscape: The Laconia Survey, vol. II. British School at Athens. London.

CHAPMAN J. 1994. The origins of farming in south east Europe. Préhistoire Européenne 6: 133-156.

CHAVAILLON J., CHAVAILLON N. and HOURS F. 1967. Industries paléolithiques de l'Elide. I - Région d' Amalias. Bulletin de Correspondance Hellénique XCI: 151-201.

1969. Industries paléolithiques de l'Elide. II - Région du Kastron. Bulletin de Correspondance Hellénique XCIII: 97-151.

CHRISOSTOMOU P. 1996 (1997). I Neolithiki katoikisi sti voreia paraktia zoni tou allote Thermaikou Kolpou (eparchia Giannitson). To Archaiologiko Ergo sti Makedonia kai Thraki 10 A: 159-172.

CULLEN T. 1995. Mesolithic mortuary ritual at Franchthi Cave, Greece. Antiquity 69(263): 270-289.

DAVIS J. L. 1992. Review of the Aegean Prehistory I: the islands of the Aegean. American Journal of Archaeology 96(4): 699-756.

EFSTRATIOU N. and AMMERMAN N. J. in press (2003). Survey in Aegean Thrace: exploring the landscape. In Iacovou M. (ed.), Archaeological field survey in Cyrpus. Past history, furure potentials.

EFSTRATIOU N., KARETSOU A., BANOU E. and MARGOMENOU D. in press. The Neolithic settlement of Knossos. New light on an old picture. British School at Athens Supplement Series.
GEBAUER A. B. and PRICE T. D. (eds.) 1992. Transitions to Agriculture in Prehistory. Prehistory Press, Madison, (Monographs in World Prehistory no. 4).

GOPHER A., ABBO S. and LEV-YADUN S. 2001. The "when", the "where" and the "why" of the Neolithic revolution in the Levant. In M. Budja (ed.), Documenta Praehistorica XXVIII: 49-62.

GRONENBORN D. 1997. Silexartefackte der ältestbandkeramischen Kultur. Universitäts-forschungen zur prähistorischen Archäologie Band 37. Verlag Dr. Rudolf Habelt GMBH, Bonn.

HALSTEAD P. 1996. The development of agriculture and pastoralism in Greece: when, how, who and what? In Harris D. R. (ed.), The Origins and Spread of Agriculture in Eurasia: 296-309.

HANSEN J. M. 1991. The Palaeoethnobotany of Franchthi Cave, Excavations at Franchthi Cave, Greece, fasc. 7. Indiana University Press, Bloomington and Indianapolis.

HAYDEN B. 1992. Contrasting expectations in theories of domestication. In A. B. Gebauer and T. D. Price (eds.), Transitions to Agriculture in Prehistory: 11-20.

HEUN M., BORGHI B. and SALAMINI F. 1998. Einkorn wheat domestication site mapped by DNA fingerprinting. In M. Budja (ed.), Documenta Praehistorica $X X V:$ 65-77.

HEUN M., SCHÄFER-PREGL R., KLAWAN D., CASTANA R., ACCERBI M., BORGHI B. and SALAMINI F. 1997. Site of einkorn wheat domestication identified by DNA fingerprinting. Science 278: 1312-1314.

HUOT J.-L. 1994. Les premiers villageois de Mésopotamie: $d u$ village à la ville. Armand Colin, Paris.

JACOBSEN T. W. 1993. Maritime mobility in the Prehistoric Aegean. Paper presented at the XXth meeting on Maritime Archaeology, Nafplion (manuscr).

JAMESON M. H., RUNNELS C. and VAN ANDEL T. H. 1994. A Greek Countryside: the Southern Argolid from Prehistory to Present Day. Stanford University Press, Stanford.

JEUNESSE C. 2000. Les composantes autochtones et danubienne en Europe centrale et occidentale entre $5500 \mathrm{BC}$ et 4000 av. J. C.: contacts, transferts, accul- 
turations. Les derniers chasseurs-cueilleurs d'Europe occidentale, actes du colloque international de Besançon, Besançon octobre 1998. (Annales littéraires 699; Série: Environnement, sociétés et archéologie, 1): 361-378.

2002. La coquille et la dent. parure de coquillage et évolution des systèmes symboliques dans le Néolithique danubien (5600-4500). In Guilaine J. (ed.), Matériaux, productions, circulations $d u$ Néolithique à l'Âge du Bronze: 49-64.

KOTSAKIS K. 1992. 0 neolithikos tropos paragogis. Ithagenis i apoikos. Diethnes synedrio gia tin Archaia Thessalia sti mnimi tou Dimitri P. Theochari, Ekdosi Tameiou archaeiologikôn porôn kai apallotrioseôn: 120-135.

2001. Mesolithic to Neolithic in Greece. Continuity, discontinuity or change of course? In M. Budja (ed.), Documenta Praehistorica XXVIII: 6373.

KYPARISSI-APOSTOLIKA N. 2000. Theopetra Cave. Twelve years of excavation and research 19871998. Proceedings of the International Conference, Trikala, 6-7 november 1998, Athens 2000.

2003. The Mesolithic in Theopetra Cave: new data on a debated period of Greek Prehistory. In Galanidou N. and Perlès C. (eds.), The Greek Mesolithic, British School at Athens Studies (BSA series, no. 10): 189-198.

LADIZINSKY G. 1989. Origin and domestication of the Southwest Asian grain legumes. In D. R. Harris and G. C. Hillman (eds.), Foraging and Farming. The evolution of plant exploitation (One World Archaeo$\log y$ ): 374-389.

LARSSON L. 1990. The mesolithic of southern Scandinavia. Journal of World Archaeology 4(3): 257309.

LEV-YADUN S., GOPHER A. and ABBO S. 2000. The craddle of agriculture. Science 288: 1062-1063.

LICHARDUS-ITTEN M., DEMOULE J.-P., PERNICEVA L., GREBSKA-KULOVA M. and KULOV I. 2002. The site of Kovacevo and the beginnings of the neolithic period in southwestern Bulgaria. In Lichardus-Itten M., Lichardus J. and Nikolov V. (eds.), Beiträge zu jungsteinzeitlichen Forschungen in Bulgarien: 99-158.
MANEM C. 2002. Structure et identité des styles céramiques du Néolithique ancien entre Rhône et Èbre. Gallia Préhistoire 44: 121-165.

MOUNDREA-AGRAFIOTI A. 2003. Mesolithic fish hooks from the Cave of Kyklops. In Galanidou N. and Perlès C. (eds.), The Greek Mesolithic, British School at Athens (BSA series, no.10 ): 131-141.

MYLONA D. 2003. The exploitation of fish resources in Mesolithic Sporades: Fish remains from the Cave of Kyplops, Yioura. In Galanidou N. and Perlès C. (eds.), The Greek Mesolithic, British School at Athens (BSA series, no. 10): 181-188.

NEWTON S. 2003. The mesolithic fauna from Theopetra. In Galanidou N. and Perlès C. (eds.), The Greek Mesolithic, British School at Athens no. 199-205.

ÖZDOGAN M. 1997. The beginning of the Neolithic economies in Southern Europe: an Anatolian perspective. Journal of European Archaeology 5(2): $1-33$.

2001. The Neolithic deity: male or female? In Boehmer R. M. and Maran J. (eds.), Lux Orientis. Festschrift für Harald Hauptmann: 313-318.

PERLÈS C. 1979. Des navigateurs méditerranéens il y a 10000 ans. La Recherche 96: 82-83.

1987. Les industries lithiques taillées de Franchthi (Argolide, Grèce). Tome I: Présentation générale et industries paléolithiques, Excavations at Franchthi Cave, fasc. 3. Indiana University Press, Bloomington/Indianapolis.

1988. New ways with an old problem: chipped stone assemblages as an index of cultural discontinuity in the early Greek Prehistory. In E. B. French and K. A. Wardle (eds.), Problems in Greek Prehistory. Papers presented at the Centenary Conference of the British School of Archaeology at Athens, Manchester, April 1986: 477-488.

1989. La néolithisation de la Grèce. In 0. Aurenche and J. Cauvin (eds.), Néolithisations: Proche et Moyen Orient, Méditerranée orientale, Nord de l'Afrique, Europe méridionale, Chine, Amérique du Sud, British Archaeological Reports, Int. Series. 516: 109-127.

2001. The Early Neolithic in Greece. The First Farming Communities in Europe. Cambridge 
University Press, Cambridge (Cambridge World Archaeology).

POWELL J. 2003. The fish bone assemblage from the Cave of Kyklops, Yioura: evidence for continuity and change. In Galanidou N. and Perlès C. (eds.), The Greek Mesolithic, British School at Athens (BSA series, no.10): 173-179.

RADOVANOVIĆ I. 1996. The Iron Gates Mesolithic. International Monographs in Prehistory, Ann Arbor (Archaeological series 11).

RENFREW C. and ASPINALL A. 1990. Aegean obsidian and Franchthi Cave. In C. Perlès (ed.), Les industries lithiques taillées de Franchthi (Argolide, Grèce). Tome II: Les Industries du Mésolithique et du Néolithique initial, Excavations at Franchthi Cave, fasc. 5: 257-270.

ROUDIL J.-L and SOULIER M. 1983. Le gisement néolithique ancien de Peiro Signado (Portiragnes, Hérault): étude préliminaire. Actes du XXIe congrès préhistorique de France, Quercy, 1979: 258-279.

RUNNELS C. 1994. A Palaeolithic survey of Thessaly. La Thessalie. Quinze années de recherches archéologiques, 1975-1990. Bilans et perspectives, Tome 1: 55-56.

1995. Review of Aegean Prehistory IV: The Stone Age of Greece from the Palaeolithic to the advent of the Neolithic. American Journal of Archaeo$\log y$ 99: 699-728.

1988. A Prehistoric survey of Thessaly: new light on the Greek Middle Palaeolithic. Journal of Field Archaeology 15: 277-290.

SACKETT J. 1977. The meaning of style in archaeology. American Antiquity 42(3): 369-380.

THISSEN L. 2000a. A Chronological framework for the Neolithisation of the Southern Balkans. Karanovo. III. Beiträge zum Neolithikum in Südosteuropa: 193-212.

2000b. Thessaly, Franchthi and Western Turkey: clues to the Neolithisation of Greece? In M. Budja (ed.), Documenta Praehistorica XXVII: 141-154.

2000c. Early village communities in Anatolia and the Balkans, 6500-5500 BC. Ph.D. diss., University of Leiden.
TRANTALIDOU K. 2003. Faunal remains from the earliest strata of the Cave of Kyklops (Youra, northern Sporades): recording the data. In Galanidou N. and Perlès C. (eds.), The Greek Mesolithic, British School at Athens (BSA series, no. 10): 142-179.

VAN ANDEL T. and RUNNELS C. N. 1995. The earliest farmers in Europe. Antiquity 69(264): 481-500.

WEINBERG S. S. 1970. The Stone Age in the Aegean. Cambridge Ancient History I, Part 1. Cambridge University Press, Cambridge, revised. ed.: 557-618, 664-672.

WELLS B. ed., with the coll. of Runnels, C. 1996. The Berbati-Limnes Archaeological Survey 1988-1990. Acta Instituti Atheniensis Regni Sueciae, series in $4^{\circ}$, XLIV: 457-458.

ZAMANIS A., SAMARAS S., STAVROPOULOS N. and DILLE J. 1988. Report of an expedition to rescue germplasm of wild species of wheat and relatives in Greece. Greek gene bank scientific bulletin, North Greece agricultural research center.

ZILHAO J. 1993. The spread of agro-pastoral economies across Mediterranean Europe: a view from the far West. Journal of Mediterranean Archaeology 6(1): 5-63.

2000. From the Mesolithic to the Neolithic in the Iberian peninsula. In Price T. D. (ed.), Europe's first farmers: 144-182.

2001. Radiocarbon evidence for maritime pioneer colonozation at the origins of farming in West Mediterranean Europe. Proceedings of the National Academy of Sciences 98(24): 14180-14185.

ZVELEBIL M. and LILLIE M. 2000. Transition to agriculture in eastern Europe. In Price T. D. (ed.), $E \boldsymbol{~}$ rope's first farmers: 144-182.

ZVELEBIL M. 2001. The agricultural transition and the origins of Neolithic society on Europe. In M. Budja (ed.), Documenta Praehistorica XXVIII: 1-26. 